Stefanny Magdalena Susanto

KP A / 130119012

\title{
Influence of contingency theory, moderating variable, and mediating effect on firm performance
}

Maksud dari contingency theory dalam (Pratono, 2016) adalah perusahaan dapat mencapai kinerja terbaik ketika struktur mereka relevan untuk menangani kontingensi yang dipaksakan oleh ukuran, teknologi, dan lingkungan mereka. Teori kontingensi memiliki maksud untuk memahami bagaimana perusahaan menyelaraskan kinerja yang diharapkan dengan lingkungan bisnis internal dan eksternal. Oleh karena itu, teori kontingensi menunjukkan perilaku perusahaan, yang diperlukan untuk kelangsungan hidup (Pratono, 2016). Pandangan kontingensi dapat memperkaya teori tentang strategi luar dengan menentukan kondisi dimana aktivitas jaringan dapat dikonfigurasi untuk mencapai hasil yang diharapkan. Pandangan kontingensi dari ikatan jaringan ini diharapkan dapat memandu perusahaan untuk membangun dan mengkonfigurasi koneksi mereka dengan pemangku kepentingan lain untuk memanfaatkan sumber daya mereka secara tepat waktu dan efektif (Peng \& Turel, 2020).

Moderating variable dalam (Pratono, 2016) dapat membawa perubahan arah pada slope atau koefisien variabel independen yang dapat berpengaruh dalam meredam efek positif dari variabel independen pada Firm Performance. Sedangkan dampak moderasi pada (Pratono, 2018) ini memberikan informasi bahwa hubungan antara perilaku pengambilan risiko dan kinerja perusahaan berubah, tergantung pada turbulensi teknologi informasi. Hasil regresi dengan variabel moderasi teknologi informasi menunjukkan bahwa pengaruh perilaku pengambilan risiko terhadap kinerja perusahaan kurang efektif di bawah turbulensi teknologi informasi tinggi. Lalu pada (Pratono, Ratih, \& Arshad, 2020) dalam turbulensi teknologi sedang, perusahaan dapat mendorong anggota tim frontliner untuk memiliki kebebasan dalam merespon kondisi pasar dengan berbagai cara yang paling relevan dengan situasi di lapangan. Perusahaan yang menghadapi kendala sumber daya dapat melihat perubahan teknologi sebagai ancaman, turbulensi teknologi yang moderating dapat membantu perusahaan mencapai kinerja yang diharapkan.

Berbeda dari ketiga artikel diatas, (Moaniba, Su, \& Lee, 2020) menggunakan moderating variable untuk menyelidiki peran moderasi dari kolaborasi antar perusahaan, dan kolaborasi antar 
negara. Sehingga dari penelitian yang dilakukan, baik kolaborasi antar perusahaan maupun lintas negara memiliki efek moderasi positif yang signifikan pada hubungan antara jarak geografis dan profitabilitas perusahaan. Sedangkan dalam (Suoniemi, Waarden, Munzel, Zablah, \& Straub, 2020) moderating variable berpengaruh terhadap strategi bisnis yaitu hubungan antara market linking, Market-directed capability dan market orientation terhadap kinerja perusahaan.

Mediating Effect adalah suatu metode statitstik yang menjelaskan proses antara independent variable dan dependent variable. Selain itu, Mediating Effect juga menjelaskan keterkaitan hubungan antara dua variabel yang berbeda (Wang, L., et al, 2020). Mediating effect dapat dilakukan dengan menggunakan variabel observasi dan / atau variabel laten (Duan, Wang, \& Zhou, 2020). Dalam penerapannya mediating effect biasa digunakan dalam proses analisis interaksi antara variabel yang berbeda. Pengaruh yang dihasilkan dari mediating effect ini mengacu pada pengaruh tidak langsung antara variabel independen terhadap variabel dependen melalui pengaruh variabel mediasi. Sehingga penerapan mediating effect ini ikut berkontribusi dalam memperdalam pemahaman hubungan antara independent variable dan dependent variable saat variabel ini tidak memiliki keterkaitan hubungan langsung yang jelas (Tang, Li, Hu, \& Wu, 2020).

Mediating Effect dalam (Pratono, A.H., Darmasetiawan, N.K., Yudiarso, A. and Jeong, B.G, 2019) menjelaskan bagaimana keterkaitan hubungan variabel mediasi yang beroperasi sebagai receiving the input dari independent variable yang juga ikut berperan sebagai exogenous constructs, sedangkan keunggulan kompetitif perusahaan sebagai output. Dalam penerapannya, mediating effect menunjukan pengaruh yang signifikan dalam proses mencapai firm performance. Sedangkan dalam (Pratono, A. H, 2018) mediating effect diterapkan untuk mengidentifikasi keterkaitan hubungan antara social media dengan variabel mediasi. Terkait akan hal itu, terdapat beberapa hal tentang mediating effect. Mediating effect of trust, yang meyakini suatu kepercayaan turut memiliki peran penting dalam perekonomian dan juga dapat membantu mempromosikan bentuk organisasi yang adaptif. Mediating effect of selling capability, mengacu pada seberapa jauh suatu Perusahaan dapat mengelola berbagai produk yang diproduksi kepada masyarakat. Mediating effect of pricing capability, kondisi dimana suatu perusahaan dapat menetapkan harga berdasarkan cerminan nilai pelanggan yang perolehan informasinya bergantung pada kualitas struktur jaringan. Dalam hal ini, mediating effect menunjukan hubungan yang signifikan dalam proses penerapannya guna mencapai firm performance. 


\section{Bibliography}

Duan, Y., Wang, W., \& Zhou, W. (2020). The multiple mediation effect of absorptive capacity on the organizational slack and innovation performance of high-tech manufacturing firms: Evidence from Chinese firms. International Journal of Production Economics, 229, 107-114.

Moaniba, I. M., Su, H.-N., \& Lee, P.-C. (2020). Geographic distance between co-inventors and firm performance: Themoderating roles of interfirm and cross-country collaborations. Technological Forecasting \& Social Change, 157, 70-120.

Peng, G., \& Turel, O. (2020). Network ties in the outside-in strategy: Contingencies of resource endowments and absorptive capacity. Industrial Marketing Management, 91, 373-384.

Pratono, A. H. (2016). Strategic orientation and information technological turbulence : Contingency perspective in SMEs. Business Process Management Journal, 22(2), 368-382.

Pratono, A. H. (2018). Does firm performance increase with risk-taking behavior under information technological turbulence?: Empirical evidence from Indonesian SMEs. The Journal of Risk Finance, 19(4), 361-378.

Pratono, A. H. (2018). From social network to firm performance: The mediating effect of trust, selling capability and pricing capability. Management Research Review, 41(6), 680-700.

Pratono, A.H., Darmasetiawan, N.K., Yudiarso, A. and Jeong, B.G. (2019). Achieving sustainable competitive advantage through green entrepreneurial orientation and market orientation: The role of inter-organizational learning. The Bottom Line, 32(1), 2-15.

Pratono, A. H., Ratih, R. V., \& Arshad, D. (2020). Does Entrepreneurial Autonomy Foster SME Growth Under Technological Turbulence? The Empirical Evidence from Indonesia. Journal of Technology in Behavioral Science, 3, 170-178.

Suoniemi, S., Waarden, L. M., Munzel, A., Zablah, A. R., \& Straub, D. (2020). Big data and firm performance: The roles of market-directed capabilities and business strategy. Information \& Management, 57(7), 21-28.

Wang, L., et al. (2020). Performance shaping factors dependence assessment through moderating and mediating effect analysis. Reliability Engineering and System Safety, 202, 2-4. 